\title{
Proteus rettgeri
}

National Cancer Institute

\section{Source}

National Cancer Institute. Proteus rettgeri. NCI Thesaurus. Code C86693.

A species of facultatively anaerobic, Gram-negative, rod shaped bacteria assigned to the phylum Proteobacteria. This species is motile, indole, citrate, and urease positive. P. rettgeri is an opportunistic pathogen associated with nosocomial outbreaks, bacteremia, skin infections, and traveler's diarrhea. 